\title{
LANDLORD AND TENANT - A NEW LEASE OF LIFE FOR THE DOCTRINE OF SPECIFIC PERFORMANCE
}

\author{
Oonagh Breen, Lecturer in Law, University College, Dublin \\ INTRODUCTION
}

\begin{abstract}
When is specific performance available? Being an equitable and therefore discretionary remedy, this has not always been an easy question to answer. In fact the converse question has often resulted in a more fruitful list of certainties, in that the courts in the past had less difficulty in setting out the situations in which the remedy would not be considered an appropriate answer to the problem at hand. Thus, law students learned that specific performance would not be available where, for example, damages would be an adequate remedy, ${ }^{1}$ or undue hardship would be caused to the defendant, ${ }^{2}$ or it would be futile, ${ }^{3}$ or in cases concerning contracts of service, to name but a few. In recent times, however, it has begun to appear that in time honoured equitable fashion not even this negative list is sacred, with gradual inroads occurring.
\end{abstract}

For instance, the courts traditionally refused to grant specific performance of a service contract on the ground that if it was for personal services its enforcement would be tantamount to slavery and in most other cases the need for continual supervision by the court would make it impossible to justify. The law, or rather Equity, has not stood still on this matter, however, and there have been a number of departures from this particular principle in the recent past. Indeed, it may be that the winds of change have not yet finished blowing, at least on this side of the Irish sea, if the interlocutory decision of Costello P. in Wanze Properties (Ireland) Ltd v Five Star Supermarket and Tesco (Ireland) $\mathrm{Ltd}^{4}$ is anything to go by.

The potential implications of this case will be of immense interest to property lawyers concerning as it does the issue of remedies available for breach of covenant in commercial leases, in this case a shopping centre lease between the centre owner and its anchor tenant. Given the fact that the High Court decision comes hot on the heels of a similar case in England, where the House of Lords reached a contrary conclusion on the availability of specific performance, this would seem to heighten the need for a timely consideration of the law in this area.

\section{THE ENFORCEMENT OF BUSINESS OBLIGATIONS}

The twin fears of continual supervision and the enforcement of personal service are best illustrated by the cases of Ryan $\mathrm{v}$ Mutual Tontine Association ${ }^{5}$ and Ogden v Fossick. ${ }^{6}$ Interestingly both cases arose in the context of Landlord and Tenant relationships. In the former a lease of an apartment block provided for the employment of a resident porter to

1 Wilson v Northampton \& Banbury Junction Railway Co. (1874) 9 Ch App 279.

2 Smelter Corporation v O'Driscoll [1977] IR 305.

3 See the comments of Porter MR in Gorringe $v$ Land Improvement Society [1899] 1 IR 142, at 152 in relation to agreements to lend money.

4 Unreported High Court, 24 October 1997.

5 [1893] 1 Ch 116

64 De G. F. \& J. 426. 
service the building. When the appointee failed to fulfil his duties the lessee took an action against the lessor for breach of the covenant and sought to enforce the terms of the agreement by specific performance The Court of Appeal unanimously reversed the decision of Smith $\mathbf{J}$ and refused to grant specific performance. Lord Esher MR described the arrangement as "a contract between a landlord and his tenant, by which the former undertakes to employ a porter to perform certain services for the benefit of the latter"7 rather than as a contract for personal services. Nevertheless, he refused relief on the ground that such a contract, being one where the services in question were to be performed during the whole of the term of the tenancy, was in essence a long-continuing contract and would therefore require continual supervision by the Court if specific performance were granted. Moreover both Kay and Lopes LJJ pointed to the fact that an award of damages in this case could adequately compensate the breach of covenant. ${ }^{8}$

Similarly in Ogden v Fossick ${ }^{9}$ an action by the lessor of a coal wharf to enforce the lease proved unsuccessful as the agreement also provided for the employment of the lessor. Given that the latter clause was an integral part of this composite contract the court exercised its discretion not to grant specific performance. Commenting on the role of specific performance in such cases, Knight Bruce LJ stated,

"That there are terms and provisions in this agreement which the Court cannot enforce is clear beyond all doubt. The Courts cannot for instance decree the Plaintiff to carry on the business, the carrying on of which is essential to the complete performance of the entire agreement. It is scarcely less clear, that it is not according to the general course of the Court to decree the specific performance of part of an agreement when there are other terms of the same agreement which it is beyond its power to enforce." 10

Thus the early cases very clearly illustrated the courts' adversity to compelling a party to carry out business obligations, even if it was the case that this party was the plaintiff in the action and more than willing to do so.

\section{THE RE-EVALUATION OF EQUITY'S ROLE}

The move away from such a hard line approach, at least in respect to plaintiffs seeking to specifically enforce business obligations, can be seen in the Irish case of Lift Manufacturers Ltd $\mathrm{v}$ Irish Life Assurance and Sisk. ${ }^{11}$ There McWilliam J granted the plaintiff an interlocutory injunction prohibiting the nomination of a new subcontractor by the defendant pending the trial of the plaintiff's action for specific performance of its existing subcontract with the defendant. It seems from the report of the case that the plaintiff had been awarded a contract by the defendants to

7 Ibid. at p. 123.

8 Indeed, Kay LJ went on to say that the fact that damages would not cover any future breaches of the covenant in question was not in itself a sufficient reason to grant specific performance - "If that were sufficient, I cannot conceive of any case of a continuing contract where specific performance might not be granted." Ibid at p. 128.

9 See note 6 above.

${ }^{10}$ Ibid at p. 434, emphasis added.

${ }^{11}$ [1979] ILRM 277. 
install lifts at the ILAC Centre in Dublin. Owing to a delay in the auditing of the plaintiff's books it could not provide the necessary indemnity guarantee bond by the date stipulated in the agreement but it claimed it would be well in place prior to the undertaking of work at the Centre. On the plaintiff's application for an injunction to restrain the defendants terminating their contract, the latter argued that the injunction should be refused, as specific performance of a contract for services could not be decreed. Dealing with this objection, McWilliam J commented,

"As to the first objection, I have been referred to Hounslow London Borough Council v Twickenham Garden Development [1971] Ch 233; Garrett v Barnstead \& Epsom Downs Railway Ltd (1864) 4 De GJ \& Sm. 462 and Cork Corporation v Rooney (1881) 7 IR Ir. 191 which indicate that the rule is not rigid and that where there is a genuine claim an injunction may be granted. The basis for the rule is that the court cannot oversee the performance of the services and it seems to me that, where there does not appear to be any reason for the court to oversee such performance, the rule is not applicable."12

Indeed Megarry $\mathbf{J}$ had commented in a similar vein seven years earlier in the case of $C H$ Giles \& Co Ltd v Morris, ${ }^{13}$ where speaking of equity's role in respect of the enforcement of personal service or continuous service contracts, he stated

"In general, no doubt, the inconvenience and mischief of decreeing specific performance of most of such contracts will greatly outweigh the advantages, and specific performance will be refused. But I do not think that it should be assumed that as soon as any element of personal service or continuous services can be discerned in a contract the court will, without more, refuse specific performance. Of course, a requirement for the continuous performance of services has the disadvantage that repeated breaches may engender repeated applications to the court for enforcement. But so may many injunctions; and the prospects of repetition, although an important consideration, ought not to be allowed to negative a right. As is so often the case in equity, the matter is one of balance of advantage and disadvantage in relation to the particular obligations in question; and the fact that the balance will usually lie on one side does not turn this probability into a rule. The present case, of course, is a fortiori, since the contract of which specific performance has been decreed requires not the performance of personal services or any continuous series of acts, but merely procuring the execution of an agreement which contains a provision for such services or acts."

In both instances the respective judges were willing to look beyond the dogma and consider the reasoning behind such an approach in equity. In Lift Manufacturers, while the decree of specific performance would require the defendants to accept labour provided by the plaintiffs in line with their original agreement, the implication was that this would be within the scope of the remedy because there had been no loss in faith on the defendants' part in the ability of the plaintiffs to perform the task in hand. Despite their disagreement over preliminary matters, the mutual trust and integrity essential to any business relationship still existed in this case.

12 Ibid at $\mathrm{p} 280$.

${ }^{13}$ [1972] 1 All ER 960, at 970. 
Indeed, the judgment of McWilliam $\mathrm{J}$ may be contrasted with that of Barr $\mathrm{J}$ in the case of Marine Port and General Workers Union $\mathrm{v}$ Pandoro Ltd ${ }^{14}$ where the learned judge refused to grant an interlocutory injunction to the plaintiffs to prevent the defendants from hiring dock workers other than from its union register. Acknowledging that to grant the relief sought would be tantamount to ordering the defendants to employ the plaintiff's workers, Barr $\mathrm{J}$ made the point that where there remains bona fide doubt as to the competence and experience of a work force, specific performance is not a suitable remedy. In the words of the learned judge,

"The foisting on a reluctant employer of a work force not chosen by the employer and about which it has bona fide misgivings, whether well founded or not, is likely to be a recipe for trouble which, pending a full hearing at the trial of the action, would not seem to be in the best interest of either party." 15

In essence, it could be said that the lack of mutual trust and integrity between the parties here led the court to find as it did.

\section{THE EXTENSION TO LANDLORD AND TENANT LAW}

It is here that we turn our attention to landlord and tenant law and the relatively limited role played by specific performance in this area in the past. Prior to the decision in Wanze Properties (Ireland) Ltd v Five Star Supermarket and Tesco (Ireland) Ltd, ${ }^{16}$ a breach of a covenant in a lease could be dealt with in a number of ways. If the parties were the original parties to the lease, privity of contract enabled either side to sue for breach of its covenants. Subsequent successors in title of either the landlord or tenant could in turn rely on sections 12 and 13 of the Landlord and Tenant (Amendment) Act 1860, respectively. ${ }^{17}$ At common law the main remedy available was that of damages if the damage was quantifiable. This was subject, however, to statutory modification in a number of instances. ${ }^{18} \mathrm{In}$ terms of statutory rights both the 1860 and the 1980 Acts provide for forfeiture and ejectment. The theoretical relief available from equity includes injunctions and specific performance. Thus, for instance it is possible for a tenant to seek relief from equity where a landlord fails to carry out repairs in line with his obligations under the lease. ${ }^{19}$ In practical terms, however, the intervention of equity is more often exercised in

${ }^{14}$ Unreported, High Court, 3 June 1994.

${ }^{15} \mathrm{Ibid}$ at $\mathrm{p} 5$.

${ }^{16}$ See note 4 above.

${ }^{17}$ Commonly known as Deasy's Act sections $12 \& 13$ of the 1860 Act provide for a statutory version of the common law notion of privity of estate. See Lyle $\mathrm{v}$ Smith [1909] 2 IR 58.

${ }^{18}$ See, for example, s 65 of the Landlord and Tenant (Amendment) Act 1980, which limits the amount of damages actually recoverable for breach of a covenant to repair to the diminishment of value caused to the reversion (s 65(2)) and in stated circumstances prevents recovery by the landlord from the tenant altogether (s 65(3)), provided in both instances that the damage is not the result of wilful waste or wrong on the part of the tenant.

${ }^{19}$ Wylie, Irish Landlord and Tenant Law, p 423, who notes that specific performance would only be available in such a case where the Court is satisfied that it is clear exactly what needs to be done to comply with the order. See, for example, Bernard v Meara (1861) 12 Ir Ch R 389. 
providing relief against forfeiture for non-payment of rent. ${ }^{20}$ Indeed, it seemed clear that in line with equity's general principles in relation to specific performance where there was a lack of mutuality specific performance would not be available.

What then is the situation where the court is asked to grant equitable relief for breach of a covenant in a lease that obliges the tenant to continue to carry on a business? Is such a covenant open to specific performance or the granting of an injunction to enforce its terms? Or should damages be seen as an adequate remedy? What if it is proven that damages will not be an adequate remedy, does it follow that specific performance should then be granted in order that justice be done between the parties?

\section{THE ENGLISH APPROACH}

The issue is one which had raised its head a number of times in the United Kingdom in the past. In Braddon Towers Ltd $\mathrm{v}$ International Stores Ltd ${ }^{21}$ the Court refused to grant the plaintiffs a mandatory injunction to compel their defendant tenants to abide by a covenant in their lease to keep their supermarket open at all normal times and to use their utmost endeavours to develop, improve and extend the business and not to do or suffer anything to injure the goodwill. The defendants, on discovering their venture to be a loss making one, had closed the premises without consulting the landlords and in clear breach of the trading covenant in the lease. Drawing on the wisdom of Pennycuick $\mathbf{J}$ in Dowty Boulton Paul Ltd v Wolverhampton Corp. ${ }^{22}$ Slade LJ stated,

"It is very well established that the court will not order specific performance of an obligation to carry on a business or, indeed, any comparable series of activities."

It was in light of such authorities that the case of Co-operative Insurance Society Ltd $\mathrm{v}$ Argyll Stores (Holdings) Ltd ${ }^{23}$ came before Judge Maddocks in the English High Court. The dispute between the parties concerned the anchor tenant unit at the Hillsborough Shopping Centre in Manchester. Argyll Stores held the lease of this unit for a term of 35 years from August 1979 and used it as a Safeways supermarket outlet. One of the covenants in the lease required the tenants to use the premises as a supermarket and to keep that premises open for retail trade during the usual hours of business. $^{24}$ The lease also allowed for the tenants to assign their interest

$-$

${ }^{20}$ Blake v Hogan (1933) 67 ILTR 237. Cf Cue Club Ltd. v Navaro Ltd. unreported, Supreme Court, 23 October, 1996 where the Supreme Court held that the nature of the equitable discretion exercised by the courts in granting a lessee relief against forfeiture is hardly applicable or applicable to the same extent where the court is dealing with substantial commercial transactions in which the lessor and lessee are on equal terms.

21 (1979) [1987] 1 EGLR 209.

22 [1971] 2 All ER 277 at 284 (court refusing to grant an injunction to compel the maintenance of an airfield as a going concern). See also Hooper $v$ Broderick (1840) $11 \mathrm{Sim} 47$ (court refusing to order a lessee carry on loss making business as an inn, in spite of a positive covenant in the agreement to that effect); $A-G$ (ex rel Allen) $v$ Colchester Corporation [1955] 2 All ER 124 (refusal of an injunction to compel a ferryman to carry on a ferry business which was a losing concern on the ground that an injunction should not be granted to enjoin a person to carry on a business).

23 [1996] 3 All ER 934 (Court of Appeal); [1997] 3 All ER 297 (House of Lords).

${ }^{24}$ Clause 4 (19) required the defendants to 
during the life of the lease. In 1995, following trading losses for the previous year, the defendants decided to sell 26 Safeway stores including its anchor unit at the Hillsborough Centre. In pursuit of this aim and in spite of the trading covenant, the defendants closed the supermarket and stripped the store in May 1995. ${ }^{25}$

The High Court gave summary judgment in favour of the plaintiffs (with damages to be assessed) but refused an order for specific performance against the defendants to compel them to keep their store open in line with the trading covenant. ${ }^{26}$ It was from this decision that the plaintiffs appealed to the Court of Appeal, consisting of Leggatt, Roch, and Millet LJJ, which by a two to one majority allowed the appeal.

The majority of the Court of Appeal ${ }^{27}$ took the view that damages would be an inadequate remedy in this case as it would be impossible to quantify the scale of loss, extending as it would beyond those losses of the plaintiff itself to the other tenants of the shopping centre, many of whom would have signed leases in the knowledge that Safeways was the anchor tenant. Turning to the availability of specific performance, Roch LJ felt that the Court was in a position to specify quite clearly what was required of the defendants in any such order, namely that they continue to trade in accordance with the terms of their agreement either until 2014 or until a suitable assignee could be found. Continual supervision was unlikely to be a problem as it would be against the reputation and goodwill of the defendants to trade in any manner other than an efficient one. Such an order found support in decisions such as Morris v Redland Bricks, ${ }^{28} \mathrm{CH}$ Giles \& Co $\mathrm{v}$ Morris ${ }^{29}$ and Braddon Towers, ${ }^{30}$ the judges in those cases indicating that in exceptional circumstances the jurisdiction to grant such relief as was claimed here should be exercised unhesitatingly. Concluding his judgment Leggatt LJ added

"The defendants have acted with gross commercial cynicism, preferring to resist a claim for damages rather than keep an unambiguous promise. This is not a court of morals, but there is no reason why its willingness to grant specific performance should not be affected by a sense of fair dealing."

\footnotetext{
$-$

"Keep the demised premises open for retail trade during the usual hours of business in the locality and the display windows properly dressed in a suitable manner, in keeping with a good class parade of shops provided that the tenant may close the demised premises: (a) For one day between Monday and Friday inclusive in each week of the term and (b) For a period not exceeding four months for the purposes of handing over the demised premises to an assignee or under-tenant following an assignment or under-letting under the terms of Clause 4(15) hereof"

${ }^{25}$ The plaintiffs had written to the defendants on learning of their intention and asked them to keep the store open on a lesser rent until an assignee could be found. It appears from the House of Lords report that this letter remained unanswered as its addressee had also fallen victim of the rationalisation plan and was himself made redundant before the letter arrived!

${ }^{26}$ This was in spite of the learned judge's finding that the defendant's conduct would cause serious damage to the reversion and that damages would not be adequate remedy, see [1996] 3 All ER at 946.

${ }^{27}$ Millet LJ dissenting,

28 [1970] AC 652.

${ }^{29}$ See note 13 above.

${ }^{30}$ See note 21 , above.
} 
In his dissent Millet LJ set out the settled practice of the court not to grant a final injunction or specific performance where the effect of such an order would be to compel the defendant to carry on a business indefinitely. ${ }^{31}$ Looking at the rationale behind the court's approach in these cases, his Lordship admitted that the motivations of the court were varied - ranging from the impossibility of supervision on the part of the court to what Millet LJ described as "sounder objections" in that the court would not make an order obliging the defendant to do continuous acts involving labour and care. Reviewing the comment of Slade LJ in the Braddon Towers case ${ }^{32}$ that it might be possible to define an order in precise enough terms so as to make specific performance possible in cases of this nature, Millet LJ found fundamental objection to such a suggestion,

"If granted for any length of time or for an indefinite period, it is oppressive. To compel a defendant for an indefinite period to carry on a business which he considers is not viable, or which for his own commercial reasons he has decided to close down, is to expose him to potentially large unquantifiable and unlimited losses which may be out of all proportion to the loss which his breach of contract has caused to the plaintiff." 33

Recognising the age-old conflict ${ }^{34}$ between the fundamental freedom of a party to break a contract and pay in damages and what others regarded as "an intolerable travesty of justice" that a party should be able to disentangle himself from contractual commitments at his own pleasure merely by electing to compensate the other with damages, Millet LJ drew attention to the pragmatic middle ground which the English courts had adopted in resolving such disputes. He noted,

"Equitable relief is discretionary and exceptional. Courts of equity have never enforced the performance of all contracts, whatever their nature. Over the centuries rules of practice have evolved so that the parties can know in advance which contractual obligations will be specifically enforced and which sound in damages only. The leading principle is usually said to be that equitable relief is not available where damages are an adequate remedy.... But this is not the only test of the appropriateness of equitable relief.... Equitable remedies are instruments of justice; they should be refused where they would be potential instruments of oppression." 35

The fact that the lease had a further nineteen years to run weighed heavily with his Lordship. Conceding that he would be willing to depart from some of the older grounds advanced for declining to make such an order, Millet LJ concluded that he remained "firmly of the view that the court ought not compel a party to carry on a business for an indefinite period regardless of the financial consequences of doing so."

${ }^{31}$ Citing authorities such as Hooper v Broderick (1840) 11 Sim 47, Lord Abinger v Ashton (1873) LR 17 Eq 358, and Dowty Boulton Paul Ltd v Wolverhampton Corp. [1971] 2 All ER 277 in support of this statement.

32 [1987] 1 EGLR 209, at 213-214.

33 [1996] 3 All ER 934, at p 948 (emphasis added).

${ }^{34}$ His Lordship pointed out that such controversies had persisted even in the times of Sir Edward Coke and Lord Ellesmere LC.

${ }^{35}$ See note 33 above at p 949 . 
The House of Lords unanimously allowed an appeal from the decision of the Court of Appeal and ordered the restoration of the decision of Maddock $\mathrm{J}$ in the High Court. Lord Hoffman giving the judgment for the House raised for consideration a number of issues of importance. Citing as a main objection to the decree of specific performance the potential for imprecision in the order of the Court, it was noted that this could create a situation where it would be unclear to the defendant what exactly was required of him or her. The significance of this hurdle lay in the fact that the failure by a defendant to comply with an order for specific performance left him open to the threat of contempt proceedings. ${ }^{36}$ Commenting on the sanction of contempt, Lord Hoffman stated,

"This is a powerful weapon; so powerful, in fact, as often to be unsuitable as an instrument for adjudicating upon the disputes which may arise over whether a business is being run in accordance with the terms of the court's order. The heavy-handed nature of the enforcement mechanism is a consideration which may go to the exercise of the court's discretion in other cases as well, but its use to compel the running of a business is perhaps the paradigm case of its disadvantages . .."37

Drawing a distinction between circumstances where specific performance might be sought by a plaintiff, his Lordship felt the cases could be neatly divided into those where a result was sought to be achieved 38 and secondly situations where an order is sought to compel the defendant to carry on an activity. Of the two instances the learned judge felt that only the former should be subject to specific performance and even then not every obligation to achieve a result would be specifically enforceable. The rationale behind this was that only in result cases can a court really say whether the defendant has complied with the order - the finished product ending the need for the involvement of the court. However, in cases where an activity such as running a business is the subject of proceedings, it is not feasible to continually return to court to ensure that the spirit and not merely the letter of the order is complied with.

Moreover, the court availed of the opportunity to clarify the meaning of Lord Wilberforce's comments in Shiloh Spinners Ltd v Harding ${ }^{39}$ where the learned judge had remarked, "[w]here it is necessary, and, in my opinion right, to move away from some 19th century authorities, is to reject as a reason against granting relief, the impossibility for the courts to supervise the doing of work." Lord Wilberforce had made his comments in the course of a result orientated specific performance case, but his views had been relied on in later cases by judges as being applicable to specific performance in a general sense, thereby confusing the issue. ${ }^{40}$

${ }^{36}$ In the words of Lord Hoffman, "The less precise the order, the fewer the signposts to the forensic minefield which he has to traverse" at p 303.

${ }^{37}$ Ibid at $\mathrm{p} 302$.

${ }^{38}$ Lord Hoffman stated that in these situations the order could by its nature be precisely defined by the court and consequently its effectiveness could be more easily monitored. Examples of "result orders" would include the enforcement of building contracts, as in Wolverhampton Corp. v Emmons [1901] 1 KB 515 and repairing covenants in leases, as in Jeune v Queens Cross Properties Ltd [1973] 3 All ER 97.

39 [1973] 1 All ER 90 at 102.

40 Shiloh itself concerned liability under a covenant of repair but was applied generally by the Court in Tito $v$ Waddell (No. 2) [1977] 3 All ER 129, not to mention by Leggatt LJ in the instant case at [1996] Ch 286 at $292-293$. 


\section{Loss Making Concerns}

Given that the defendants were involved in a loss making entity, the Court considered the wisdom of prolonging the battle. The view expressed was to the effect that it would hardly be in the public interest in such a situation to continue when an alternative existed in the form of compensation - "It is not only a waste of resources but yokes the parties together in a continuing hostile relationship. The order for specific performance prolongs the battle. ... This is wasteful for both parties and the legal system." 41

\section{The Interpretation of Covenants}

The interpretation of the covenants by the court should also provide food for thought given that such standard clauses are in use in many commercial leases.

It held that even a straightforward trading covenant, as in this case, was broad enough to give room for argument as to whether a tenant is doing enough to comply with the covenant. In so finding the House expressly disagreed with the view of the majority in the Court of Appeal that once an order was made that the defendants would for the sake of their business reputation make full efforts to comply with its terms. ${ }^{42}$ It stated,

"If ordered to keep the business open, it might well decide that the next best strategy was to reduce its costs as far as was consistent with compliance with its obligations, in the expectation that a lower level of return would be more than compensated by higher returns from additional expenditure on more profitable shops. It is in my view wrong for the courts to speculate about whether [the defendant] might voluntarily carry on business in a way which would relieve the court from having to construe its order." 43

These comments arguably apply equally to going concerns as to loss making concerns and certainly there is nothing in Lord Hoffman's speech which would indicate an intention to so limit their applicability. ${ }^{44}$

\section{The Role of Equity in Modern Commercial Relations}

So whither the role of equity in a commercial case of this nature? The Court acknowledged the ethical backbone of equity's principles but looked to commercial realities in respect of broken promises, reiterating the significance of arms length negotiations,

"Both landlord and tenant in this case are large sophisticated commercial organisations and I have no doubt that both were aware that the remedy for breach of the covenant was likely to be limited to an award of damages. The interests of both were purely financial; there was no element of personal breach of faith. .."45

${ }^{41}$ At $\mathrm{p} 305$.

${ }^{42}$ See $\mathrm{n} .28$ above and accompanying text.

43 [1997] 3 All ER 297, at 306-307.

44 If anything the learned judge's consideration of the unquantifiable loss Argyll would suffer by continuing to trade is an additional factor as opposed to the raison d'etre behind the judge's comments extracted above.

${ }^{45}$ See note 43 above, at p 307-308. 


\section{Northern Ireland Legal Quarterly [Vol. 50, No. 1]}

Concluding that while Argyll's decision would undoubtedly have an adverse effect on the remaining tenants at the shopping centre, Argyll had no covenant with such traders and indeed the plaintiffs had not made any warranty to these third parties in relation to the defendant's anchor tenancy. ${ }^{46}$ "On the scale of broken promises, [the court] could think of worse cases." 47

\section{THE CURRENT POSITION IN IRELAND}

The arrival of British supermarket multiples on this side of the Irish sea has had a knock-on effect on existing landlord and tenant relationships, particularly with regard to trading covenants. In some instances the influx of competition has caused a downturn in rivals' business resulting in anchor tenants wishing to leave the market or rationalise their holdings. In other cases the take-over of Irish supermarkets, with the subsequent investment of new capital, has led the new owners to seek to relocate to premises more in keeping with their newly acquired image, thereby shedding former obligations.

In Northern Ireland, the former situation arose in Ravenseft Properties Ltd v Stewarts Supermarkets Ltd and Crazy Prices ${ }^{48}$ where the defendant, in breach of its trading covenant, had sought to close its unit at the Towermill shopping centre in face of competition from the arrival of Sainsburys at a nearby shopping centre. The plaintiffs sought orders prohibiting cessation of the supermarket business and specific performance of the trading covenants in the lease.

Girvan $\mathrm{J}$ in the High Court, admitted that he was placed in an unenviable position in so far as the English Court of Appeal had given its decision in Argyll but the House of Lord's decision was still pending. Counsel for the defendant argued that in light of the wording of the relevant trading clause ${ }^{49}$ it would be impossible to formulate a clear mandatory order. Drawing on the authority of Fawcett Properties v Buckinghamshire County Council, ${ }^{50}$ where the Court had held that a court in construing a contract should not hold it void for uncertainty unless it cannot resolve the ambiguity, Girvan J felt a high degree of assurance that a mandatory injunction could be drafted in sufficiently clear terms. In so holding the learned judge granted the injunction sought limited to the date of the House of Lords ruling in Argyll. Describing the circumstances before him as "exceptional", he stated that to refuse the injunction (thereby allowing the lessee to close) would give rise to greater injustice than granting the order should it appear at the trial of action that he had made the wrong decision.

$-$

46 The court went so far as to suggest that the loss to the other tenants was, if anything, a bargaining tool which they could use in negotiations at the next rent review.

${ }^{47}$ See note 43 above at $\mathrm{p} 308$.

${ }^{48}$ Unreported, 6 May 1997, Girvan J.

${ }^{49}$ Clause 2 (11) in part stated that the defendants covenanted:

"Not during the first 18 years of the term without the lessor's consent to use or permit or suffer the demised premises or any part thereof to be used otherwise than as a general supermarket....provided that not less than half of the net sales area is used as a supermarket for the sale of food and such hardware and non food lines as are normally sold in similar food supermarkets elsewhere......and to keep the demised premises for (sic) such purposes during normal trading hours...."

${ }^{50}$ [1960] 3 All ER 503, at 508. 
A similar dilemma presented itself recently to the Irish High Court. In Wanze Properties (Ireland) Ltd v Five Star Supermarket and Tesco (Ireland) $L_{t d}{ }^{51}$ the Court was asked to grant an interlocutory injunction to compel the defendants, (anchor tenants in the plaintiff's shopping centre), to reopen their store for business in line with the trading covenant in their lease. ${ }^{52}$ The defendants had taken a commercial decision to break their lease with Wanze by relocating to a new shopping centre a mere 400 yards away from the plaintiff's premises in Athlone. A significant difference between the facts of this case and the situation in Argyll and one which was fully stressed by counsel for the plaintiffs was that in the present case, the supermarket was not a loss making concern at the time it decided to relocate. The motivation here was rather one of increasing profitability as the second defendants had recently acquired the first defendants and were in the process of modernising and updating their holdings. The issue was whether this factual distinction between the two $\operatorname{cases}^{53}$ was sufficient to warrant Costello P granting an interlocutory injunction on the ground that there was a reasonable probability that an order of specific performance would be made at trial. ${ }^{54}$ While Ravenseft was not cited to the Court, arguably the facts in Wanze were even more extreme in that the supermarket here had been closed and stripped of its fixtures, whereas in the former at the time interlocutory relief was sought the store was still trading.

Costello P sought to ascertain whether there was an arguable case to be made by the plaintiffs. Evidence was produced before the Court that if the defendants were allowed to walk away from the 12-year term still remaining on the lease, the loss to the plaintiff would be catastrophic. Finding in favour of the plaintiff on the existence of a serious question to be tried the learned judge also felt that damages would not be an adequate remedy should the plaintiffs prove their case at a full trial of the action. In particular, he stated,

"I am quite satisfied that if the Court decides that it has power to grant an injunction or an order of specific performance, it would so do. It would not give damages in lieu because damages would be an entirely inadequate remedy." 55 (emphasis added)

The significance of the President's comments in this regard should not be overlooked. The very issue as to whether the High Court should grant specific performance of a business contract for an indefinite or continuous period of time was not decided. The actual merits of such a decision could only be made after full oral argument and not on the basis of affidavit evidence produced for the purpose of an interlocutory, and therefore

${ }^{51}$ See note 4 above.

${ }^{52}$ Covenant 11 in the lease in question provided that the tenant was,

"To keep the demise (sic) premises, or such portion thereof as is normally open to the public, open for the purpose of the said trade during the usual hours of business appropriate to the tenant's business, at least unless required to close by law or trade union regulation."

${ }^{53}$ That is between breaching a trading covenant on the basis of non viability of the business in question (as in Argyll) and breaching a covenant in pursuit of a deliberate commercial decision to seek higher returns elsewhere (as in Wanze).

${ }^{54}$ See note 4 above, at $\mathrm{p} 2$ of the judgment. The defendants had indicated a willingness to pay damages but argued that the Court had no jurisdiction to grant specific performance in a case of this nature.

${ }^{55}$ Ibid at $\mathrm{p} 4$. 


\section{Northern Ireland Legal Quarterly [Vol. 50, No. 1]}

necessarily tentative, relief. Consideration was given to the House of Lords decision in Argyll with reference being made by the learned judge to the headnote of the case "that the decision of the House of Lords indicated a rule of law which should be applied other than in exceptional circumstances. ${ }_{56}$

To this end, the learned President made an order directing the defendants to carry on the supermarket trade in the premises in question, allowing the defendants three working days to properly staff the premises again and to remove signs indicating its closure. ${ }^{57}$

\section{ANALYSIS}

It is certainly arguable as to whether specific performance should be available to the plaintiffs in Wanze. Indeed one hopes that the issue will proceed to a substantive hearing so that the issues arising may be fully teased out as they were by the House of Lords in Argyll. Even in the absence of any further litigation, a number of points may be made in respect of Costello P's judgment. Firstly, the learned judge commented that the difference between the present case and Argyll was that in Wanze it would be open to the plaintiffs to argue that the financial loss the defendants would suffer as a result of being required to carry on business in the Athlone centre was attributable to their own actions. The implication was that this allocation of fault to the defendants would thereby strengthen (or rather, not detract from) the plaintiff's claim for specific performance. However a close reading of the House of Lords decision indicates that the Lords did not think it right to differentiate between the motivation for and the breach itself - "although any breach of covenant is regrettable, the exercise of the discretion as to whether or not to grant specific performance starts from the fact that the covenant has been broken." 58 Indeed Millet LJ in the Court of Appeal expressly stated that specific performance was not an appropriate remedy where, either for reasons of viability or "for his own commercial reasons", a tenant decides to close a business. ${ }^{59}$ Obviously if there was a gross breach of personal faith or attempts to blackmail the other party by threatening nonperformance, the considerations would be different. In the ordinary instance of commercial relations, however, it is, with all due respect, a little disingenuous to suggest that the circumstances arising in Wanze constituted the "exceptional circumstances" referred to in the headnote of Argyll which might so warrant a departure from the settled practice of refusing specific performance in such instances. ${ }^{60}$

The Irish authorities relied on by Costello P may be dealt with in a similar fashion. The Lift Manufacturers case, while being in point, concerning as

$-$

${ }^{56}$ Ibid at $\mathrm{p} 3$.

${ }^{57}$ It is understood that the defendants have not appealed this decision to the Supreme Court.

${ }^{58}$ See note 43 above, at $\mathrm{p} 307$.

${ }^{59}$ See note 33 above and accompanying text.

${ }^{60} \mathrm{As}$ in most cases the actual text of the House of Lords decision in Argyll elaborates on the concept of "exceptional circumstances" mentioned in the headnote and which the trial judge in Wanze found so appealing. Indeed, Lord Hoffman does not actually refer to "exceptional circumstances" himself but rather gives illustrations of situations which have been summarised correctly by the headnoter as being exceptional. Such instances however, when considered in the context of his Lordship's judgment would not include a commercial decision to relocate in the interests of doing better business. 
it does the specific enforceability of a business contract, can be distinguished from the present case. In that case, as was noted above, ${ }^{61}$ the issue revolved more around the technicalities of the plaintiff's availability to do the work. It is arguable that if the situation had been reversed so that for whatever reason the lift company had no longer wished to work for the main contractor, the latter would not have been able to get an order of specific performance against them compelling them to install the lifts. Another authority mentioned in passing by Costello $\mathrm{J}$ is the case of $A \& N$ Pharmacy v United Drug Wholesale Ltd. ${ }^{62}$ In this case an interlocutory injunction was granted to the plaintiff compelling the defendant to supply the former pending the trial of action. While this may seem, therefore, an authority in favour of specific performance of business transactions, it again can be distinguished on its facts. In $A \& N$, the plaintiff's main argument was that the defendant was in a dominant position and that its conduct towards $\mathrm{A} \& \mathrm{~N}$ amounted to an abuse, contrary to section 5 of the Competition Act 1991. The injunction was granted because there were serious issues to be tried that such a statutory breach had taken place, and not on the basis that the court would just exercise its discretion otherwise to compel parties to do business. A final authority referred to by the learned judge was the decision of McCracken J in Barlo Farm Machinery $v$ Case United Kingdom Ltd. ${ }^{63}$ In that case the learned judge granted the plaintiffs an interlocutory injunction compelling the defendants to continue to supply them with agricultural machinery spare parts, pending the resolution of the dispute over the termination by the latter of the plaintiff's exclusive dealership. In so doing McCracken J. pointed out that the net issue in that case was whether sufficient notice of termination had been afforded to the plaintiffs.$^{64}$ Finding that a serious question therefore arose to be tried, he ordered the continued supply of parts to the plaintiffs pending trial. The decision in Barlo is arguably correct in so far as it goes. It is clear from the judgment that the parties were not disputing the actual termination of the relationship itself but merely the timeframe in which it was carried out. To compel the continued supply of parts on a cash on delivery basis pending a full hearing is substantially different from compelling a party to "trade on" for an indefinite period of time. Moreover, McCracken $\mathrm{J}$ in Barlo noted the unhelpfulness of other authorities cited to him stating that "each case must stand on its own facts". Secondly, even Costello J in Wanze noted that while the cases cited seemed to indicate a certain development of the law in this respect it "[had] not yet gone as far as that urged by [the plaintiffs]." 65

The compelling points raised by both Millet LJ and Lord Hoffman remain to be answered by the Irish courts. The essence of the Argyll decision would seem to be that where one has a lease with a number of years to run which contains a standard covenant to trade, breach of this covenant should sound in damages only. The rationale behind this is twofold compelling a tenant to trade for an indefinite period of time is oppressive, given the sanction for breach and this remains the case regardless of the

${ }^{61}$ See $\mathrm{p} 3$ in general.

${ }^{62}$ Unreported High Court, 15 February 1996; [1996] Irish Competitition Law Reports 358.

${ }^{63}$ Unreported High Court, 24 October 1996.

${ }^{64}$ The dealership arrangement dated back to 1948 and it was argued by the plaintiffs that in light of the length of their association with the defendants they ought to have been given at least 12 months notice as opposed to the six months actually given.

${ }^{65}$ At $\mathrm{p} 2$ of the judgment. 


\section{Northern Ireland Legal Quarterly [Vol. 50, No. 1]}

reason for the tenant's wish to cease. Secondly, given the language of standard covenants to trade their enforceability would be impossible by the court in the absence of guidelines as to the level of trade required. In the words of Lord Hoffman, "running the business efficiently does not necessarily mean running in the way it was run before."

\section{CONCLUSION}

A number of options remain open to the High Court in deciding the substantive issues of relief raised by Wanze. Girvan $\mathrm{J}$ in Ravenseft considered the alternatives open to the House of Lords in anticipation of its ruling and it is submitted that as the High Court may soon be at a similar crossroads, those options are worthy of consideration. Being threefold, he suggested it was open to the court to hold that neither specific performance nor mandatory injunctions should be available in the situations discussed above; secondly it would be open to the Lords to rule that save in exceptional circumstances such an order should be made in the case of clear contractual provisions. Finally it may consider that every case must be considered on its own facts and it could decide to offer guidance as to the factors to be taken into account by courts in the exercise of that discretion.

The House of Lords has chosen the well-travelled road of principle. The Irish High Court stands at the divergence.

\footnotetext{
${ }^{66}$ See note 43 above, at $\mathrm{p} 306$.
} 